\title{
O que faz mover as redes sociais? Uma análise das normas e dos laços
}

What makes social networks move? An analysis of norms and ties

Ce qui fait mouvoir les réseaux sociaux? Une analyse des normes et des liens

\section{Sílvia Portugal}

\section{OpenEdition}

\section{Journals}

Edição electrónica

URL: http://journals.openedition.org/rccs/723

DOI: $10.4000 /$ rccs. 723

ISSN: $2182-7435$

\section{Editora}

Centro de Estudos Sociais da Universidade de Coimbra

Edição impressa

Data de publição: 1 Dezembro 2007

Paginação: 35-56

ISSN: 0254-1106

Refêrencia eletrónica

Sílvia Portugal, "O que faz mover as redes sociais? Uma análise das normas e dos laços », Revista Crítica de Ciências Sociais [Online], 79 | 2007, colocado online no dia 01 outubro 2012, criado a 21 abril 2019. URL : http://journals.openedition.org/rccs/723 ; DOI : 10.4000/rccs.723 


\title{
SÍLVIA PORTUGAL
}

\section{O que faz mover as redes sociais? Uma análise das normas e dos laços*}

\begin{abstract}
Neste artigo pretende-se discutir as normas que regulam a acção dos laços informais na produção de bem-estar. Mostra-se que a acção das redes sociais obedece aos princípios gerais do sistema de dádiva, revelando-se como a tríplice obrigação "dar, receber, retribuir" estrutura as práticas e representações dos actores. No entanto, expõem-se, igualmente, os problemas decorrentes desses princípios orientadores. Reciprocidade, obrigação, igualdade, autonomia - as normas surgem claras, mas a sua análise detalhada desvenda princípios contraditórios, resistências, tensões e conflitos.
\end{abstract}

\section{Introdução}

Este artigo parte de uma pesquisa empírica que analisou o papel das redes sociais na provisão de recursos (Portugal, 2006) para discutir as normas que regulam a acção dos laços informais na produção de bem-estar. A pesquisa, de carácter qualitativo, teve como base 60 entrevistas em profundidade realizadas a homens e mulheres, integrados/as no mercado formal de trabalho, a viver em situação de conjugalidade, com ou sem filhos, com idades compreendidas entre os 25 e os 34 anos. Optei, assim, por centrar a análise na fase inicial do ciclo de vida familiar, procurando um tempo de (re)organização de recursos materiais e afectivos, para testar o papel das redes sociais.

A pesquisa desenhou a morfologia das redes das famílias, identificando redes de interacção, redes de troca e redes de íntimos, e analisou os fluxos no interior das redes, identificando para recursos diversos (emprego, habitação, saúde, bens materiais) qual o papel dos diferentes tipos de laços. Este trabalho mostrou claramente a permanência e vitalidade do sistema de dádiva na circulação de bens e serviços. Os dados empíricos evidenciam, por um lado, a centralidade das redes sociais na satisfação das necessidades

\footnotetext{
* Agradeço aos colegas do Conselho de Redacção da Revista Crítica de Ciências Sociais e, em especial, ao Claudino Ferreira, os seus comentários a este texto.
} 
das famílias, mostrando como os laços informais são essenciais no suporte quotidiano da vida familiar. As entrevistas realizadas revelam como no interior das redes circulam inúmeros recursos, apoios, afectos, bens e serviços. Por outro lado, a análise da morfologia das redes accionadas para cada um dos recursos permite verificar como para cada domínio é accionada uma rede parcial (Boissevain, 1974) em que são activados os laços que melhor podem responder às necessidades dos indivíduos e das suas famílias. Deste modo, se, para certos recursos, a rede se centra nos laços fortes ${ }^{1}$ e de parentesco, para outros, os laços fracos são essenciais para garantir a provisão das necessidades.

Neste artigo pretende-se avaliar as normas que regulam estes fluxos intensos. Se a pesquisa mostra que a circulação das trocas no interior das redes obedece aos princípios gerais do dom, tal como foram enunciados por Marcel Mauss em Ensaio sobre a dádiva, originalmente publicado em $1924,{ }^{2}$ os discursos das pessoas entrevistadas revelam, também, o carácter ambíguo e contraditório destes princípios, permitindo trazer à luz a sua complexidade.

\section{Normas e laços}

Por definição, as normas dizem aos indivíduos como eles devem comportar-se e o que devem esperar dos outros. As normas reduzem a incerteza e contribuem para definir "como devem ser as coisas" num determinado grupo. Os problemas surgem quando o comportamento dos actores foge às normas estabelecidas ou as suas expectativas são goradas. As normas podem dividir-se em três tipos principais (Therborn, 2002): as normas constitutivas, que definem o sistema de acção e a pertença do actor a esse sistema; as normas reguladoras, que regem as contribuições esperadas do actor para o sistema; as normas distributivas, que definem como devem ser distribuídas as recompensas, custos e riscos. Noutras palavras, as normas definem a pertença ao grupo, a contribuição esperada e a recompensa adequada para essa contribuição. Para Therborn, estes três tipos de normas têm uma importância diferenciada e diferentes dinâmicas: as normas constitutivas, ou de conduta, têm um significado primordial, dado que são as que estão mais interiorizadas, definindo o que

\footnotetext{
${ }^{1}$ Para a distinção entre laços fortes e laços fracos utilizaram-se os critérios dos trabalhos de Granovetter $(1973,1982)$ : duração da relação (antiguidade da relação e tempo dispendido conjuntamente), intensidade emocional, intimidade, serviços recíprocos. A estes adicionou-se um quinto critério, sugerido por Degenne e Forsé (1994): a "multiplexidade", ou seja, a pluralidade de conteúdos de troca existente num laço.

2 Para uma interessante análise da obra de Mauss e da sua actualidade, cf. Martins (2005).
} 
constitui uma pertença total, adequada a determinado sistema social. São elas que permitem ao indivíduo "comportar-se". No entanto, as normas distributivas tendem a obter as reacções mais violentas pela sua violação. O sentimento de injustiça tende a ser um motor fundamental para a acção. Quanto às normas reguladoras, elas são um critério importante para a atribuição do estatuto no interior do sistema social (Therborn, 2002: 870).

O que se pretende neste artigo é avaliar o papel destas normas, e os problemas levantados pela sua aplicação, no interior das redes sociais. Por que é que uma pessoa ajuda a outra? Por que é que uma pessoa recebe ajudas de outra? Que expectativas têm dadores e receptores? Que normas regulam as trocas no interior das redes? O que é considerado certo e errado, justo e injusto? Como se definem as obrigações? Laços diferentes obedecem a princípios diferentes?

A pesquisa aponta para uma resposta afirmativa a esta última questão, condicionando, assim, em grande parte, as respostas às restantes questões. As normas que regulam a interacção no interior das redes dependem do tipo de laço que está em jogo. O que está certo ou errado, o que é devido ou não, o que é justo ou injusto depende da natureza da relação em causa. As normas reflectem uma relação entre as pessoas, mais do que um equilíbrio entre coisas trocadas. Como concluem Kellerhals et al. (1995), o sentimento de justiça traduz, em primeiro lugar um projecto relacional, um "reconhecimento das pessoas".

Os trabalhos de Jean Kellerhals e dos seus colaboradores sobre os critérios que regulam a justiça distributiva (quem tem direito a quê?) e processual (como chegar a decisões justas?) têm feito escola (Kellerhals et al., 1995; 1987 e 1988). No seu livro Figures de l'équité. La construction des normes de justice dans les groupes (Kellerhals et al., 1988), os autores identificam cinco questões genéricas que estruturam a definição de justiça nos grupos. Uma primeira decisão diz respeito à norma de repartição: que regra utilizar para distribuir os bens raros? A necessidade, o mérito, a igualdade ou ainda outro critério? Mas colocar este princípio em acção implica, em segundo lugar, a intervenção de normas de avaliação, ou seja, de critérios que permitam definir o valor das contribuições e a situação dos membros do grupo que participam na troca. Em terceiro lugar, a norma de comparação define a forma como o estatuto e a identidade social são importantes para a decisão interna de justiça: estas categorias são ignoradas ou, pelo contrário, são tão importantes que as normas de repartição e avaliação funcionam em função delas? Qualquer destas opções pode ser afectada pela natureza do bem em jogo, pelo que, em quarto lugar, aplica-se uma regra de transformação: 
pode ou não utilizar-se as mesmas regras e os mesmos critérios para distribuir bens de natureza diferente?

Finalmente, os autores sublinham que estes quatro aspectos da decisão de justiça estão condicionados pelo problema da norma de apropriação. Trata-se de saber como o grupo constitui a massa de bens sobre os quais posteriormente procede a uma repartição. A norma de apropriação define se os títulos de propriedade individual que prevalecem fora do grupo são conservados no seu interior ou se, pelo contrário, o grupo define a todo o momento os direitos de propriedade dos seus membros. No primeiro caso, o indivíduo define as fronteiras do grupo, no segundo caso, é o inverso que acontece.

A pesquisa permite concluir que a aplicação destes critérios ao conjunto da rede depende da natureza e da força dos laços e também do recurso em jogo. Ou seja, as normas de comparação (qual é o laço da rede) e de transformação (qual é o bem em causa) prevalecem sobre a norma de repartição. Por um lado, os critérios que definem a justiça entre contribuições e retribuições aplicam-se de forma diferente, dentro e fora da rede de parentesco. Como afirma Alexis Ferrand, "a grandeza, por vezes, o horror, dos laços familiares está na capacidade de decretar a equivalência de valor entre ajudas totalmente heterógeneas" (Ferrand, 1992: 89).

Por outro lado, o tipo de bem em jogo obriga a rever a aplicação das normas. Bens de natureza diferente obrigam a critérios diferentes, dentro e fora da família. Se os pais têm mais do que um filho e fazem uma doação de dinheiro a um deles, a norma que prevalece é a da igualdade - todos devem receber o mesmo. No entanto, se os avós tiverem mais do que um neto e tomarem conta apenas do que vive mais próximo, o critério aceite é o da conjugação da necessidade com a proximidade.

Estas conclusões são semelhantes às de Jacques Godbout na sua reflexão sobre $\mathrm{a}$ aplicação das normas de justiça às relações de parentesco (Godbout, 1995). O autor analisa três circuitos de troca distintos - a ajuda em serviços, os presentes e a hospitalidade - e conclui que os critérios que regulam cada um deles são distintos. Godbout chega a uma conclusão final, para a qual também aponto: a norma da justiça é de difícil aplicação no interior da rede de parentesco. Como se verá de seguida, ela apenas constitui um princípio dominante quando aplicada à comparação entre diferentes retribuições para uma mesma contribuição. Ou seja, o princípio não se aplica entre um dador e um receptor, mas entre dadores ou entre receptores. Como afirma Godbout, nas redes de parentesco a ideia de justiça não diz directamente respeito à relação contribuição-retribuição, mas à comparação entre "pares" (dadores ou receptores) na sua relação com um terceiro (1995: 361). 


\section{Reciprocidade, mas...}

A primeira questão que se coloca ao olhar para os princípios que regulam as redes de trocas materiais ou afectivas é: existe uma troca restrita ou uma troca generalizada? A questão evoca as distinções fundamentais dos etnólogos e antropólogos. Contudo, não se trata aqui de aplicar a teoria completa, enunciada por Lévi-Strauss, mas de reter "a intuição da questão" (Degenne e Lebeaux, 1997: 124). Se a troca existe com base em dons e contra-dons, espera-se que se atinja uma certa forma de equilíbrio. $\mathrm{Na}$ troca restrita, uma dádiva apela a outra dádiva feita a quem deu primeiro, mesmo que esta não tenha as mesmas características. Um amigo arranjou-me um emprego, eu pago-lhe um jantar para comemorar; uma vizinha conseguiu abreviar o tempo de espera duma consulta no hospital, eu ofereço-lhe uma prenda no Natal. Existe uma reciprocidade directa, uma troca simétrica e restrita à díade. $\mathrm{Na}$ troca generalizada, o equilíbrio é estabelecido à escala do grupo. A reciprocidade é difusa e diferida no tempo. Eu ajudo o meu irmão a construir a casa dele, a minha mãe um dia vai doar-me um terreno para eu construir a minha.

Lemieux, a partir de Ekeh, defende que os dois tipos de troca têm consequências diferentes sobre a solidariedade dos grupos em que são praticados. Contrariamente ao que outros especialistas da troca têm defendido, afirma que a troca restrita é fonte de tensão e instabilidade, dado que repousa num fraco grau de confiança mútua, enquanto a troca generalizada se alicerça num forte grau de confiança no conjunto de actores envolvidos. Aquele que recebe não retribui àquele que dá, mas o dador confia que alguém no interior da rede retribuirá um dia (Lemieux, 1999: 61-62). A partir da análise dos dados de um inquérito realizado em França nos finais dos anos 80, Degenne e Lebeaux concluem que a troca generalizada caracteriza a troca no seio da família em linha directa e que a troca restrita define os fluxos horizontais, entre colaterais, amigos e vizinhos (Degenne e Lebeaux, 1997: 124-125).

Este artigo corrobora as perspectivas destes autores. A pesquisa que realizei mostra que a laços diferentes se aplicam princípios diferentes. As redes sociais definem-se com base no critério fundamental "a família/os outros" (Portugal, 2006) e as normas que se aplicam aos fluxos entre os laços obedecem ao mesmo princípio. A circulação da dádiva possui especificidades quando olhamos para dentro ou para fora da família.

Como os autores do M.A.U.S.S. ${ }^{3}$ têm vindo a sublinhar, "dar, receber, retribuir” não é sinónimo de reciprocidade (Mermet, 1991; Caillé, 2000;

\footnotetext{
${ }^{3}$ O movimento M.A.U.S.S. - Moviment Anti-Utilitariste en Sciences Sociales - fundado em 1981, tem, como explica Alain Caillé, na sua apresentação ao público brasileiro, "um sentido negativo e outro positivo". O sentido negativo prende-se com a recusa do utilitarismo, a ideologia hegemónica da modernidade. O sentido positivo procura a reflexão, a partir das ideias de Marcel Mauss sobre
} 
Godbout, 2000). Dar para que o outro dê não é o mesmo que dar para receber. A troca sob a égide do dom surge como uma sequência de acções que engendra uma assimetria de posições entre os actores envolvidos. A sequência sustenta-se numa cadeia de prestações e contra-prestações e na reversibilidade das posições de doador e de receptor. Esta é uma realidade aberta e não constrangedora, visto que a cadeia pode ser rompida ou recusada em qualquer momento por qualquer dos actores envolvidos. A dádiva dá lugar à indeterminação, à possibilidade de construir um sentido comum que não se restringe à retribuição, antes constrói uma relação em que os envolvidos nunca são apenas dadores ou receptores. A análise de práticas e comportamentos concretos mostra que a liberdade do dom, e o modo como ela se articula com a reciprocidade, obedece a um jogo complexo entre diferentes princípios, que age de forma diversa consoante os laços da rede que estão em causa. Se, até certo ponto, podemos concordar com Godbout, quando este afirma que o parentesco "mantém a reciprocidade à distância" (Godbout, 2000:34-36), é impossível não reconhecer uma lógica binária de reciprocidade nas relações fora da família.

O conceito de dívida positiva utilizado por Godbout (2000) revela-se mais produtivo para analisar a circulação da dádiva no interior da família do que o de reciprocidade. Numa relação, o estado de dívida positiva escapa à equivalência e faz com que cada um considere que recebe mais do que dá, embora esteja sempre disposto a retribuir. A definição de Godbout é bastante frutífera para perceber o dom familiar, e, sobretudo, os fluxos intergeracionais: "a dívida positiva existe quando o receptor não percebe no dador a intenção de o endividar através do seu gesto - o que está estreitamente ligado ao prazer de estar em dívida, elemento essencial do estado de dívida positiva" (Godbout, 2000: 47). Esta condição marca o discurso da maior parte das pessoas entrevistadas - dívida é a palavra mais usada para se falar das dádivas dos progenitores. Por um lado, eles deram a pró-

o dom (Caillé, 2003: 16). O Movimento, que surgiu como reacção à hegemonia do economicismo nas ciências sociais que se instalara durante a década de 70, publica actualmente a Revue du MAUSS e reúne uma série de investigadores de áreas diversas. Os autores do M.A.U.S.S. rejeitaram os raciocínios dominantes, recusando-se a aceitar o bomo economicus como concepção do indivíduo e o mercado como princípio estruturador da sociedade. Deste modo, procuraram argumentos que lhes permitissem construir uma visão alternativa do mundo. Esses argumentos foram-lhes dados pela obra de Marcel Mauss, sobretudo pelas ideias contidas no Ensaio sobre a dádiva. Esta obra contém a "descoberta" (a designação é de Caillé) crucial para o movimento: a de uma certa universalidade, nas sociedades arcaicas, da tríplice obrigação de dar, receber e retribuir. O dom apresenta-se, para Mauss, como um "fenómeno social total". Mesmo efectuada por indivíduos singulares, a dádiva diz respeito ao conjunto das dimensões da acção e repercute-se em toda a sociedade. Para além da sua dimensão utilitária, ela é, essencialmente, simbólica. Não só os dons são símbolos, como os símbolos devem ser entendidos como dons. Deste modo, "o paradigma do dom pode ser compreendido igualmente como um paradigma do simbolismo" (Caillé, 2000: 125). 
pria vida, e essa é por si uma dádiva impossível de retribuir - embora os netos sejam por vezes encarados pelos filhos como uma recompensa dada aos pais pelos seus sacríficios. ${ }^{4}$ Por outro lado, existe a noção de que é necessário retribuir de algum modo, mas que qualquer retribuição "nunca paga" o que já se recebeu. Finalmente, como já o mostraram outros estudos (Degenne e Lebeaux, 1997), existe quase um consenso sobre a inexistência de expectativas por parte dos pais dadores relativamente a uma retribuição dos seus filhos - como diz uma entrevistada, "eles [os pais] gostam muito mais de nos ajudar a nós do que nós os ajudarmos a eles”.

A dívida para com os progenitores é, simultaneamente, uma dívida económica e uma dívida de reconhecimento. Elementos materiais, afectivos e simbólicos misturam-se num jogo complexo que, no entanto, não deixa totalmente de lado a reciprocidade. Se o parentesco mantém a reciprocidade "à distância”, como diz Godbout, ele não a exclui definitivamente, antes a reveste de formas diversas: ela é "limitada" (Godbout, 2000:36), "diferida" (Bawin-Legros, 2003: 169), "indirecta” (Attias-Donfut et al., 2002: 263). $\mathrm{Na}$ reciprocidade familiar, por um lado, dádiva e retribuição fazem circular e equivaler coisas muitos diferentes; por outro lado, entre dom e contra-dom, o tempo pode correr sem que o ciclo se quebre.

Não conta o que se troca, nem quando se troca. Nesta dádiva, o tempo conta tanto menos quanto mais se confia no outro. Mediada pela afectividade e pela confiança, a reciprocidade entre parentes realiza-se muitas vezes à "escala de uma vida" e transforma a ajuda numa espécie de "crédito a longo prazo" que não necessita de ser retribuída no imediato, nem de ser simétrica: o contra-dom pode vir muito mais tarde ou mesmo ser destinado a outra pessoa (Bawin-Legros, 2003; Déchaux, 1990b; Finch, 1989). Nesta concepção, inscreve-se também uma ideia clara da evolução das posições de receptor e de dador ao longo da vida, de pais e filhos. Na infância e juventude, os filhos são apenas receptores, na idade adulta são receptores e dadores, de uma forma assimétrica, até que os pais atingem a velhice, e nessa altura passam eles a ser os receptores. A velhice dos pais é a altura em que a norma implícita da reciprocidade é posta em prática (Bawin-Legros, 2003; Grundy, 2005; Schaber, 1995).

Os cuidados dos idosos são um exemplo de como na dádiva familiar a norma da reciprocidade se estende no tempo longo da história familiar e vai para além da troca restrita. Cuidar dos pais na velhice não é apenas uma

${ }^{4}$ Deste modo, a continuidade da filiação inscreve-se no circuito amplo e no tempo longo da dádiva familiar, e é, sem dúvida, uma das formas mais claras do modo como os laços de parentesco tornam equivalente o incomensurável. 
retribuição pelas dádivas recebidas no decorrer da vida, é também uma retribuição pelas dádivas que estes fizeram aos seus próprios pais. Deste modo, o mesmo tipo de dom pode ter diferentes actores envolvidos no momento da dádiva e no momento da retribuição. Como diz um entrevistado: "eles também tomaram conta de mim, e se um dia eu quero que alguém tome conta de mim também tenho que tomar agora conta de alguém, é simples". Filhos, pais e avós fazem parte de uma cadeia intergeracional, através da qual a dádiva circula e a reciprocidade chega sempre um dia (Attias-Donfut et al., 2002).

A pesquisa permite, contudo, verificar que as características da reciprocidade no interior do parentesco dependem das características socioeconómicas das famílias. Embora a reciprocidade no tempo longo persista, entre pais e filhos de famílias mais desfavorecidas a reciprocidade directa aumenta (Jones, 1992; Martin, 1995). Este tipo de reciprocidade é sobretudo visível nas ajudas materiais. Neste domínio, a troca directa é muito mais clara: os filhos recebem bens e serviços dos pais, mas estão quase sempre obrigados a retribuições explícitas.

Fora dos laços de parentesco, tudo se passa de forma diferente. A dádiva fora da família obedece a uma lógica binária de reciprocidade. Os laços que extravasam o grupo de parentesco são alvo de desconfiança e fonte de insegurança, pelo que a troca só pode ser restrita. Não existem garantias para além da díade. Nesta, as expectativas e as exigências são elevadas, o controlo é apertado. Se me dão, eu retribuo, se eu dou, espero retribuição: o equilíbrio tem que ser mantido, sob pena de se quebrar o vínculo. Não é necessário que a dádiva tenha o mesmo conteúdo, mas é necessário que o ciclo não se quebre e se mantenha permanentemente activo para que o laço permaneça intacto.

De um modo geral, a dádiva fora da família parece ser menos gratificante e estimulante. Por um lado, a dívida fora do parentesco deixa de ser positiva e passa a ter um significado negativo. Ter uma dívida com alguém faz a pessoa sentir-se mal, por isso é preciso que se livre dela. De alguma maneira, na circulação da dádiva fora da família o princípio da equivalência mercantil inscreve-se nas representações e nas práticas. A liberdade é não dever nada a ninguém. Aqui, a reciprocidade é, também, uma condição necessária para evitar a dominação de um dos parceiros sobre o outro (Godbout, 2000: 59). Por outro lado, quando falam dos laços fora da família, as pessoas tendem a valorizar sobretudo a sua posição como dadoras, e manifestam muitas vezes sentimentos de injustiça perante o comportamento dos outros. ${ }^{5}$

\footnotetext{
${ }^{5}$ Como revela uma entrevistada na seguinte afirmação: "Eu, como é que hei-de dizer... eu quando sou amiga de uma pessoa... mas sempre assim fui... mas ainda nunca encontrei uma pessoa que fosse assim para mim, nunca... assim pessoas de fora... ainda nunca encontrei uma pessoa...".
} 


\section{Obrigação, mas...}

Até que ponto "dar, receber, retribuir" se constitui como uma obrigação? O que é que as pessoas entendem como obrigação? As relações familiares são mais marcadas pela obrigação e pelo dever do que as restantes? Janet Finch e Jennifer Mason, na obra Negotiating Family Responsibilities (1993), respondem negativamente a esta última questão, mostrando que as normas relativas ao apoio familiar são muito menos constrangedoras, e muito menos gerais, do que poderia pensar-se. No estudo que realizaram em Inglaterra, as autoras chegaram à conclusão de que, para a maioria das pessoas, as responsabilidades relativamente aos seus parentes não eram fixas, sendo muito mais fluidas do que as noções de "obrigação" ou "dever" implicam.

As autoras defendem que existe um "sentido de responsabilidade" que é desenvolvido ao longo do tempo, através da interacção entre os indivíduos envolvidos. Existe um processo de negociação no qual as pessoas dão e recebem, pesando um tipo de ajuda contra outro, mantendo uma determinada independência, assim como uma mútua interdependência. Deste modo, as responsabilidades são criadas e construídas e não dadas à partida como inerentes a uma relação específica.

Os meus dados não permitem subscrever a perspectiva destas autoras. As entrevistas revelam que as obrigações, no interior da família, estão inscritas à partida nas relações. O parentesco é um adquirido, mais do que uma construção: existe uma noção do que se espera de um parente e daquilo que ele pode esperar. A importância afectiva e instrumental da família assenta na certeza de que os seus membros partilham uma mesma noção de "como deve ser". O que as entrevistas mostram é a prevalência, nas representações dos indivíduos, de uma obrigação familiar de "cuidar dos seus".

Philippe Rospabé sublinha a ambiguidade do termo "obrigação", que se aplica a instituições diversas, onde o constrangimento é de natureza diferente (Rospabé, 1996). O autor distingue dois significados: no sentido jurídico, técnico, a obrigação define uma relação legal entre duas pessoas, em virtude da qual uma pessoa pode exigir algo da outra. ${ }^{6}$ Este laço jurídico estabelece um devedor e um credor, podendo o segundo exigir "alguma coisa" do primeiro, sob pena de uma sanção jurídica. Para além deste sentido restrito, Rospabé fala de uma obrigação em sentido lato, a obrigação moral que resulta de um compromisso, que não é obrigatório, no sentido jurídico do termo, dado que não está sujeito a sanções deste tipo, mas que funciona como um imperativo (Rospabé, 1996: 142-143).

\footnotetext{
6 "Obrigação é o vínculo jurídico por virtude do qual uma pessoa fica adstrita para com outra à realização de uma prestação” (Artigo 397. 을 Código Civil).
} 
Em Portugal, os dois significados do termo contribuem para que as obrigações familiares estruturem as representações e as práticas dos indivíduos. Podemos constatar, simultaneamente, um peso importante dos valores familistas e um enquadramento jurídico que reforça esses valores. As obrigações familiares continuam consagradas nas leis fundamentais que regem os cidadãos ${ }^{7}$ e continuam, também, a persistir nos valores que regulam as relações familiares, revelando "uma norma cultural que preconiza o mútuo auxílio entre parentes próximos" (Wall, 1998: 329), como demonstram todos os inquéritos realizados até ao momento. ${ }^{8}$

Apesar de a interiorização da obrigação familiar ser clara, encontra-se alguma rejeição do termo e uma tendência para lhe conferir um significado negativo. Existe uma recusa da obrigação familiar como forma de constrangimento ou coacção. ${ }^{9}$ Os discursos revelam uma tensão entre norma e dever, por um lado, e liberdade e afectividade, por outro lado. É como se o reconhecimento da existência de uma obrigação a priori anulasse o efeito dos afectos. Deste modo, a obrigação assume formas diversas, que tentam ultrapassar a concepção de dever imposto e conceber uma via em que "o que deve ser feito" é matizado pela dimensão relacional e pelas escolhas e os afectos individuais. Assim, as práticas de cuidar, dar, receber, retribuir, no interior da família, deixam de assentar na obrigação e passam a ser definidas como "demonstração de afecto", "retribuição", "colaboração", "partilha”, "algo que se faz com prazer". ${ }^{10}$

Esta constatação revela a relação específica do sistema de dádiva com as normas. Não só se escondem as verdadeiras regras como se enunciam outras que tendem a negar a lógica existente. ${ }^{11}$ Esta foi uma das observações que

\footnotetext{
${ }_{7}$ Numa análise das leis de filiação portuguesas, João de Pina Cabral fala do "familismo radical" que inspirou a redacção do Código Civil de 1966 (Pina Cabral, 1993: 988). As alterações de 1977 acabaram com a figura do chefe de família, estabeleceram a igualdade entre homens e mulheres e o reconhecimento dos filhos fora do casamento, mas mantiveram a consagração das obrigações entre pais e filhos, permanecendo de uma forma bastante vincada a ideia de pais e filhos se deverem auxílio mútuo.

${ }^{8}$ A esmagadora adesão dos portugueses à afirmação "devemos amar pai e mãe, independentemente das suas qualidades e defeitos" leva Ana Nunes de Almeida a afirmar que "é como se o vínculo biológico, o laço de sangue, fosse, em absoluto, um dado natural que impõe àqueles que possuem um estatuto de descendentes deveres indiscutíveis" (Almeida, 2003: 77).

9 Afirma um entrevistado: "Pronto, não é obrigação... é uma coisa... é uma coisa que eu gosto, porque os meus sogros são espectaculares, eu acho... não sei se haverá alguém que tenha uns sogros como os meus. É verdade.”

${ }^{10}$ Alcon et al. (1996), num estudo sobre os discursos acerca das obrigações familiares, realçam a diversidade de significações do conceito: desde a recusa absoluta da ideia e da defesa de que tudo é voluntário, até à convicção da necessidade da existência de um dever moral para que algo possa ser feito.

${ }^{11}$ Bourdieu fala de "tabu da explicitação" (1997: 124).
} 
Mauss fez para as sociedades arcaicas: onde o investigador vê interesse e obrigação, o discurso dos actores é o da voluntariedade e generosidade. $\mathrm{Na}$ realidade, os elementos de um sistema de dádiva têm uma relação particular com as regras. Em primeiro lugar, "as regras do dom devem ser implícitas" (Godbout, 2000: 159). Em segundo lugar, existe uma tendência generalizada para os actores negarem a obediência a um sistema de regras num gesto de dádiva. A "verdadeira" dádiva é aquela que não tem como objectivo conformar-se com uma convenção social ou uma regra, mas sim exprimir o laço com o outro.

Os discursos sobre este tema parecem revelar uma tendência contrária à identificada por outros estudos realizados no resto da Europa sobre as solidariedades familiares. Se nos outros países, sobretudo em França, os autores encontram um discurso antigo com práticas novas e falam do "novo espírito de família"12 (Attias-Donfut et al., 2002; Bawin-Legros, 2003), em Portugal, eu apontaria para a existência de práticas antigas com um discurso novo. ${ }^{13}$ Existe um "velho espírito de família", assente em obrigações claramente definidas e estruturantes das práticas dos indivíduos, que se articula com um discurso inovador, em que autonomia, independência, democracia e afectividade se revelam factores importantes para definir o que "deve ser feito" e o que "é feito".

A pesquisa mostra como as obrigações são sobretudo sentidas no interior da família, estão essencialmente ligadas aos laços de sangue e sujeitas a um processo de verticalização no interior da rede. No entanto, é possível construir obrigações com elementos da rede fora da família (Finch, 1989). Estas não são muito comuns, sendo dirigidas para os escassos laços fortes construídos através das relações de amizade. Dado que este tipo de laços é marcado pela liberdade, pela escolha e pelo risco, as obrigações exteriores à família são inteiramente construídas na relação com o outro e baseadas na reciprocidade. As exigências com as relações de amizade são muito fortes, nada é dado à partida, tudo é posto continuamente à prova pelos contributos de cada elemento da díade. As obrigações assentam na segurança da continuidade do ciclo "dar, receber, retribuir" - eu tenho obrigação de dar e receber a um amigo, porque ele faz o mesmo comigo. Aliás,

\footnotetext{
${ }_{12}$ Título do mais recente livro de Claudine Attias-Donfut, em colaboração com Nicole Lapierre e Martine Segalen (Attias-Donfut et al., 2002).

${ }_{13}$ Esta realidade não se limita às questões aqui analisadas. A coexistência, no domínio da família, de práticas tradicionais com valores e discursos progressistas tem sido sublinhada em diversos estudos. Por exemplo, no domínio da conjugalidade - muitos pensam que o casamento é uma "instituição antiquada", mas todos casam (Almeida, 2003: 54-55). Enquanto, relativamente ao trabalho doméstico, todos pensam que ele deve ser partilhado, mas apenas as mulheres trabalham (Torres et al., 2004).
} 
só lhe chamo amigo quando tenho garantias de que isso acontece. Se elas existem, então as obrigações podem ser tão fortes como as que se encontram na família.

\section{Igualdade, mas...}

O discurso das pessoas entrevistadas sobre contribuições, retribuições e obrigações no interior da rede é muito marcado pelo princípio da igualdade - "todos devem receber o mesmo", "todos têm a mesma obrigação". A igualdade parece ser um critério fundamental para definir o que é justo. No entanto, como já foi anteriormente referido, esta igualdade não se refere à reciprocidade no interior da díade dador-receptor, mas à relação entre dadores e entre receptores. Não importa se o filho retribui ao pai; importa, sim, que os pais devem dar o mesmo a todos os filhos, e que os filhos têm todos igual obrigação de cuidar dos pais na velhice. A seguinte afirmação, de uma das entrevistadas, ilustra este princípio:

O meu pai sempre fez uma coisa muito certa... se ele dá cinquenta a uma, dá cinquenta a outra. E eu nunca lhe pergunto se ele deu ou não deu à minha irmã. Mas ele é o primeiro a me dizer... eu dei xis à tua irmã, por isso vai isto para ti.

A não aplicação do princípio da igualdade na atribuição de dádivas aos filhos é dos principais motivos de tensões e conflitos entre pais e filhos e entre irmãos, e uma das razões fundamentais para as rupturas familiares. Dado que o princípio da igualdade se aplica à relação entre dadores e entre receptores, os problemas ultrapassam a díade dador-receptor e generalizam-se ao conjunto dos elementos envolvidos. Por se sentirem injustiçados, os filhos têm conflitos com os ascendentes, mas também com os colaterais, por "pactuarem" com as desigualdades. As situações de conflito no interior do parentesco restrito passam quase sempre por disputas acerca de desigualdades nas contribuições e retribuições de pais e filhos, irmãos e irmãs.

A norma da igualdade é, sobretudo, fundamental para definir a circulação da dádiva no sentido vertical descendente. Tratar os filhos todos por igual é um princípio inalienável nas relações familiares, que se reveste de particular significado quando se trata de dádivas materiais de pais para filhos. Questões simbólicas, afectivas e jurídicas contribuem para que assim seja. À obrigação moral dos pais, acrescem os direitos legais de cada um. Por esse motivo, a herança surge como um regulador final das dádivas. O princípio da igualdade pode ser, por vezes, quebrado de forma conflitual ou consensual, mas nos discursos passa a certeza de que no "final" todas as contas serão acertadas. 
A definição e aplicação do princípio da igualdade na circulação da dádiva familiar reveste-se de alguma complexidade. Coenen-Hunter $e t$ al. (1994) discutem, num estudo sobre as solidariedades familiares, a aplicação dos princípios de justiça distributiva aos processos de negociação sobre a entreajuda, chegando à conclusão de que a definição do papel dos diferentes membros da rede de parentesco na prestação de apoio se faz de acordo, fundamentalmente, com dois princípios: o da igualdade e o da equidade. O princípio da igualdade postula que todos devem contribuir de igual modo, em nome de uma similitude de estatuto. Oprincípio da equidade pressupõe, pelo contrário, que a contribuição de cada um deve obedecer a determinados critérios: recursos socioeconómicos e/ou disponibilidades concretas (tempo, proximidade geográfica, etc.); identidade sexual e ordem do nascimento (as filhas, os mais velhos, etc.); aptidões (técnicas ou relacionais). No caso do princípio de equidade, os critérios de repartição das obrigações variam consoante o tipo de ajuda que se presta (dinheiro, serviços domésticos, apoio moral, etc.) (Coenen-Hunter et al., 1994: 152).

As conclusões da minha pesquisa aproximam-se bastante daquelas a que chegaram estes autores. Em primeiro lugar, a pesquisa de Coenen-Hunter et al. revela que a norma de equidade prevalece maioritariamente sobre a da igualdade (Coenen-Hunter et al., 1994: 153). Em segundo lugar, os trabalhos sobre justiça distributiva dos autores revelam que no inventário dos recursos intervêm critérios muito diversos, na maioria das vezes geradores de conflito entre os actores envolvidos. E, finalmente, o estudo sobre as solidariedades familiares revela que muitas vezes as dificuldades são resolvidas em função dos critérios mais simples (proximidade geográfica, horários de trabalho, etc.) sem que os indivíduos envolvidos fiquem forçosamente satisfeitos.

As entrevistas que realizei mostram claramente como, dependendo do recurso em jogo, o discurso dominante sobre o princípio da igualdade é, na prática, substituído pelo princípio da equidade. Em poucos domínios a igualdade prevalece: sobretudo nas ajudas monetárias e nos bens materiais. Aqui dá-se o mesmo a todos os filhos: o mesmo dinheiro, o mesmo terreno, a mesma prenda, um valor monetário igual ao do terreno ou ao da prenda, etc. Quando se fala de ajudas em serviços e em cuidados tudo se altera: ajuda-se quem está mais perto, quem precisa mais, quem pede. O princípio da equidade passa a prevalecer e os fluxos deixam de ser regidos pela igualdade: eles são desiguais de pais para filhos, de filhos para pais, de avós para netos, de netos para avós, de irmãos para irmãos. As contribuições são diferentes consoante se é homem ou mulher, se mora perto ou longe, se pode ou não pode. É interessante sublinhar que estas ambiguidades 
são, à partida, reconhecidas no discurso dos entrevistados. As pessoas proclamam o princípio da igualdade, mas admitem as dificuldades na sua aplicação - "todos têm a mesma obrigação, mas...". Alguns atributos prevalecem sem que se levantem problemas de maior: ser mulher e morar mais próximo, por exemplo, são variáveis que "naturalmente" levam a assumir encargos acrescidos sem que existam situações de conflitualidade.

Como sublinham Coenen-Hunter et al., o princípio de equidade traduz também a expressão do individualismo e um conflito potencial entre os membros da rede de parentesco: é necessário contabilizar, mas sem que os critérios de cálculo sejam sempre compatíveis ou hierarquizáveis. Como circulam ajudas de diferentes tipos (dinheiro, bens, serviços), segundo critérios variáveis, os autores interrogam-se sobre se a dificuldade em determinar os encargos de cada um não será um elemento susceptível de limitar o volume de solidariedade. Com efeito, se o sentimento de injustiça, ligado a uma má contabilização dos critérios legítimos, pode ser tolerado enquanto os encargos são reduzidos, o mesmo não acontece forçosamente se o seu peso aumentar (Coenen-Hunter et al., 1994: 155).

\section{Autonomia, mas...}

Se o princípio da igualdade marca o discurso sobre a circulação da dádiva familiar, o princípio da autonomia caracteriza o modo como as pessoas definem a sua relação com os outros, sobretudo os ascendentes. A autonomia expressa-se desde a norma "casamento-apartamento", que preside à constituição da família e define as estratégias residenciais, ${ }^{14}$ até ao lema "cada um tem a sua vida", que é repetidamente usado para descrever o relacionamento com pais e sogros, mas também com outras relações próximas. O primado da família conjugal passa pela afirmação da autonomia e do princípio da não ingerência sobre o que se passa no seu interior. "Quem vive no convento é que sabe o que lá vai dentro" - o marido, a mulher e os seus filhos são os únicos que têm uma palavra a dizer sobre a organização da vida familiar e as decisões a tomar. Dos pormenores do quotidiano às opções profissionais e educacionais, todas as escolhas se centram nesta tríade, e qualquer interferência é considerada abusiva, sobretudo se não solicitada.

Como os processos de transição para a vida adulta são cada vez mais complexos, mais diversos e diluídos no tempo (Cicchelli e Martin, 2004;

\footnotetext{
${ }^{14}$ Uma discussão interessante sobre a relação entre a autonomia e a questão do alojamento encontra-se em Sennett (2004). O autor afirma que a propriedade da casa é um "desejo compulsivo na sociedade americana" e vê nele uma das manifestações do seu individualismo (Sennett, 2004: 112).
} 
Guerreiro e Abrantes, 2004), o “tempo da instalação” em que se encontra a maioria das famílias entrevistadas ancora-se, em grande medida, em estratégias de apoio intergeracional. As entrevistas mostram como, num contexto social em que o mercado dificulta, crescentemente, o acesso ao emprego e à habitação e a precaridade económica se instala, a autonomização dos indivíduos e das suas famílias relativamente à geração anterior é cada vez mais difícil. No entanto, ambas as gerações continuam a apostar na autonomia das jovens famílias, sendo os pais os primeiros a fornecer o suporte para que ela progressivamente se construa. ${ }^{15}$

Dados os intensos fluxos, materiais e afectivos, que circulam de pais para filhos, o equilíbrio entre dádiva, reciprocidade e autonomia é difícil de conseguir e constitui um elemento de complexa gestão no interior das famílias. Como afirma Claude Martin (1996), a dádiva familiar é acompanhada por um "direito de intromissão", que contrasta com os princípios de autonomia. A pesquisa mostra como este é um domínio de tensão no interior das redes, dado que estão em jogo normas conflituantes. O desafio que se coloca às novas famílias é conseguir um compromisso entre individualidade e liberdade, entre obrigação e autonomia, que nem sempre é fácil de atingir.

Como as reflexões do sociólogo francês François de Singly sobre família e individualização têm mostrado (Singly, 2001a, 2001b, 2001c, 2001d, 2003 e 2004), hoje, é no espaço das relações familiares, onde circula o amor, que se constrói uma grande parte da identidade pessoal dos indivíduos. Nas sociedades individualistas, "a família" (qualquer que seja a sua forma ou estrutura) tem a cargo a função de consolidar o "eu" de adultos e crianças. Contrariamente ao que o termo individualismo pode fazer crer, o indivíduo tem necessidade, para construir a sua identidade, do olhar e da relação com outros a quem ele próprio atribui importância. Estes outros significativos são, na maioria das vezes, o cônjuge e os filhos, ou os pais, se olharmos do lado das crianças.

Os trabalhos de Singly mostram como as mudanças operadas nas famílias correspondem a um compromisso entre as reivindicações de autonomia dos indivíduos e o seu desejo de continuar a partilhar a esfera privada com pessoas próximas do ponto de vista afectivo. A família "individualista e relacional" de que fala o autor (Singly, 2004) abre as portas da felicidade a cada um dos seus elementos. A relação afectiva é um quadro favorável onde a identidade pessoal não se esbate, mas, pelo contrário, se pode revelar

${ }^{15}$ Cf., sobre este assunto, o conjunto de trabalhos reunidos em Singly (2001c) sobre o processo de individualização das crianças e dos jovens. 
progressivamente. Não se trata apenas de estar junto de alguém, mas de estar junto livremente (Singly, 2001a). ${ }^{16}$

A família constrói-se com base no amor, mas o fundamental não é a instituição e sim os seus membros - "a família torna-se um espaço privado, ao serviço dos indivíduos" (Singly, 2001b: 8) ${ }^{17}$ permitindo a individualização dos seus elementos. É por esta razão que ela é simultaneamente atractiva (dado que a maioria dos indivíduos a prefere como forma de vida) e instável (o laço conjugal é cada vez mais frágil e a duração das relações cada vez mais imprevisível). Como afirma Singly, é "na tensão entre o relacional e a autonomia que se constroem, desconstroem e reconstroem as famílias contemporâneas" (ibid.).

Evito, neste artigo, cair na armadilha de confundir autonomia com independência. Como claramente elucida Karine Chaland (2001), as duas noções têm genealogias filosóficas diferentes e correspondem a realidades teóricas e empíricas bem distintas. Sinteticamente, podemos afirmar que o conceito de autonomia remete para a construção própria das regras, enquanto a ideia de independência se refere à auto-suficiência do indivíduo, à sua dotação de recursos (nomeadamente, económicos) para ser livre de estabelecer os laços que quer. Segundo os ideais individualistas das sociedades contemporâneas, os indivíduos devem ser autónomos e independentes (Singly, 2001a). No entanto, como sublinha Chaland, as duas dimensões podem não coexistir. Analisando o caso dos jovens adultos inactivos, a autora mostra como é possível ser autónomo sem ser independente (Chaland, 2001: 36-39). Entre as pessoas activas celibatárias vai encontrar a combinação "mais radical" entre as duas dimensões (ibid.: 40): indivíduos que exercem uma actividade, vivem sozinhos e não estão envolvidos em nenhuma relação íntima. A análise de Karine Chaland evidencia, com clareza, que autonomia e independência podem existir em associação ou dissociação. As minhas entrevistas confirmam esta ideia.

Se a autonomia prevalece, a independência nem sempre é uma constante. A pesquisa mostra famílias totalmente independentes das suas famílias de origem, em termos materiais e afectivos; famílias que têm relações afectivas estreitas com os ascendentes e sociabilidades intensas, mas têm total independência material; famílias que são independentes financeiramente, mas

\footnotetext{
${ }^{16}$ Este é o título de uma das obras de Singly: Libres ensembles. L'individualisme dans la vie commune (2001a). De salientar a proximidade de algumas posições do autor sobre a articulação entre individualização e vida conjugal com as teses de Anthony Giddens e o seu conceito de "relação pura" (Giddens, 1994 e 1995).

17 Esta tendência é visível através de inúmeros indicadores: o divórcio por mútuo consentimento, o aumento da participação feminina no mercado de trabalho, a preferência pela negociação na educação das crianças, etc. (Singly, 2001b e 2001c).
} 
precisam dos apoios materiais e/ou em serviços prestados pela geração anterior; famílias que dependem das suas famílias de origem para manter um estilo de vida acima dos seus rendimentos financeiros; famílias que dependem, quotidianamente, do apoio diversificado das suas famílias de origem para subsistirem.

Como mostram Hockey e James (1993), a "dependência" é uma possibilidade para qualquer indivíduo, ao longo do seu ciclo de vida. Este é um conceito que não tem apenas um significado, compreendendo um vasto leque de contextos e de experiências sociais. No entanto, actualmente, nas sociedades ocidentais, a expressão tende a referir-se a um conjunto cada vez mais estreito de experiências e a categorias específicas de indivíduos, ao mesmo tempo que assume, cada vez mais, conotações negativas. ${ }^{18}$

Estas concepções perdem sentido quando se constrói um olhar micro-sociológico sobre a família, à luz do paradigma da dádiva. Mesmo quando se reflecte de um ponto de vista macro-social, é possível observar que a extensão do período de dependência da família é cada vez maior - a juventude é um estado cada vez mais duradouro, os processos de transição para a vida adulta, como já foi referido, são, crescentemente, complexos. ${ }^{19}$ No interior da família, a dependência faz parte da trama de laços que se estabelece entre os seus elementos e da constelação de princípios, mais ou menos conflituantes, que rege as relações no interior da rede.

É a ambiguidade existente entre a exigência de autonomia e a complexa teia de dependências que a ajuda prestada pelos parentes estabelece que explica, em parte, a lógica de dissimulação que acima se discutiu. $\mathrm{O}$ dador deve tomar cuidado para não ameaçar a autonomia do destinatário e não o transformar em alguém na sua dependência. Do lado de quem recebe, é necessário assegurar a independência sem colocar em causa o apoio dos parentes. Por esse motivo, as solicitações são interditas, embora se esteja aberto à generosidade familiar. Neste jogo, têm vantagem aqueles que se sabem fazer ajudar sem pedir nada e os que dão desinteressada e discretamente.

A dependência é um termo relacional, que coloca questões sobre a natureza e a qualidade das relações que são estabelecidas. Se as teses indi-

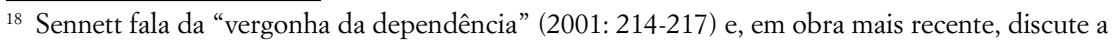
"tese da infantilização" que o pensamento liberal tem construído sobre a dependência (2004: 102-107).

19 Ao analisar os dados de um inquérito à juventude portuguesa (jovens entre os 15 e 29 anos), Luísa Schmidt chega à conclusão de que "o casamento, que consistia num dos mais seguros critérios ou indicadores de autonomização social e de mudança de estatuto de jovem para 'adulto' revela afinal prolongar uma situação caracteristicamente juvenil para muitos jovens casais", ou seja, segundo a autora, "uma situação de semidependência da família de origem" (Schmidt, 1990: 650).
} 
vidualistas enfatizam os aspectos negativos, a minha análise empírica não fornece elementos para as confirmar. As entrevistas mostram que inúmeras famílias dependem das suas famílias de origem, de diferentes modos e em diferentes graus. Embora esse facto, em alguns momentos, dê azo a algumas tensões, a dependência inscreve-se no ciclo longo de dom e contra-dom da dádiva familiar, que permite conciliar obrigação e liberdade. A pesquisa mostra como os indivíduos, e as suas famílias, procuram equilíbrios, que não colocam em causa a sua identidade e individualidade, construindo modelos que conciliam autonomia, independência e relação com os outros.

\section{Considerações finais}

Do que atrás fica exposto, decorre que a definição e a aplicação das normas no interior das redes sociais obedecem a um modelo complexo. As interacções e as trocas ancoram-se em princípios muitas vezes contraditórios entre si e geradores de tensões e conflitos. A dependência dos apoios que fluem nas redes choca com o princípio basilar da autonomia; os sentimentos de dever e de obrigação conflituam com a liberdade e a afectividade; a norma da reciprocidade ilude a assimetria das trocas; o dom coexiste com o interesse utilitário; o princípio da igualdade é obscurecido pelas desigualdades sociais e sexuais que marcam as ajudas. Este conjunto de paradoxos sustenta-se, primordialmente, na diferenciação do parentesco dos restantes laços.

A investigação que aqui se apresenta mostra que as normas têm uma aplicação diferenciada dentro e fora dos laços de família. O parentesco constitui um subsistema no interior das redes, dado que nas relações que estabelece estão inscritas a priori normas constitutivas, reguladoras e distributivas. As redes definem formas de inclusão e de exclusão, oferecem proteç̧ão ou indiferença, a partir de critérios de confiança e de desconfiança. As entrevistas mostram que o parentesco biológico oferece aos indivíduos a segurança que os outros laços não comportam, ao mesmo tempo que impõe deveres e obrigações claras.

Na obra $A$ corrosão do carácter, Richard Sennett (2001) analisa os novos tempos do trabalho e discute o modo como as instituições modernas se sustentam em esquemas que privilegiam o curto prazo, limitando, deste modo, o fortalecimento da confiança informal. O mote é "não há longo prazo" - "um princípio que corrói a confiança, a lealdade e a entrega mútua" (Sennett, 2001: 37). O autor sublinha a desvalorização dos laços fortes e a importância dos laços fracos, num contexto de permanente mudança, em que o distanciamento e a cooperação superficial são mais benéficos do que a lealdade e o compromisso. Sennett identifica um conflito entre trabalho 
e família, esfera em que o compromisso mútuo e o longo prazo são fundamentais. Deste conflito, o autor extrai algumas questões sobre a "experiência adulta": como se procuram objectivos de longo prazo numa sociedade de curto prazo? Como se podem manter relações sociais duradouras? Como pode um ser humano desenvolver uma narrativa de identidade e história de vida numa sociedade composta de episódios e fragmentos? (Sennett, 2001: 41).

Perante o que acima se apresentou, a resposta a estas perguntas parece residir nos laços de parentesco. Uma das linhas que sustenta a força dos laços familiares é a perenidade das relações. O laço de parentesco oferece a perspectiva de longo prazo que falta às outras relações, mais susceptíveis às mudanças de diferentes tipos e à erosão pelo tempo. É a permanência das relações familiares, garantida pelo laço biológico, que permite, em larga medida, a construção da confiança e do compromisso mútuo que constituem âncoras instrumentais e afectivas para os indivíduos e as suas famílias. Deste modo, os laços de parentesco constituem-se como elementos estruturadores do desenho das redes sociais.

Assim, no processo de individualização da contemporaneidade, a fragilização do laço conjugal (Singly, 2001b) e do laço profissional (Sennett, 2001) não vão, neste caso, de par com a fragilização do laço de parentesco. O papel e a normatividade das relações familiares revelam-se de múltiplas formas, permitindo afirmar a sua vitalidade e importância na configuração das redes sociais. Se, como afirma Martuccelli, "o indivíduo existe apenas na medida em que é sustentado por um conjunto de suportes” (2002: 63), a pesquisa mostra que os laços de parentesco são um suporte fundamental.

A análise das normas, no interior das redes, mostra que o parentesco tem propriedades alquímicas: torna equivalente o que não o é; permite a dependência sem perder a autonomia; concilia liberdade e obrigação; transforma a dívida num elemento positivo. Esta alquimia é possível graças ao predomínio do sistema de dádiva e ao primado do laço social sobre as coisas, na definição das relações entre os indivíduos.

\section{Referências bibliográficas}

Alcon, Carmen Dominguez; Bertaut, Mónica Becue; Reinert, Max (1996), "Obligations familiales et solidarité. Analyse statistique du texte des entretiens”, in AAVV, Ménages, familles, parentèles et solidarités dans les populations méditerranéennes. Paris: PUF. Almeida, Ana Nunes de (2003), "Família, conjugalidade e procriação: valores e papéis", in Jorge Vala et al. (org.), Valores sociais: mudanças e contrastes em Portugal e na Europa. Lisboa: Imprensa de Ciências Sociais, 47-93. 
Attias-Donfut, Claudine; Lapierre, Nicole; Segalen, Martine (2002), Le nouvel esprit de famille. Paris: Éditions Odile Jacob.

Bawin-Legros, Bernadette (2003), Le nouvel ordre sentimental. À quoi sert la famille aujourd'bui? Paris: Payot.

Boissevain, Jeremy (1974), Friends of Friends. Networks, Manipulators and Coalitions. Oxford: Basil Blackwell.

Bourdieu, Pierre (1997), Razões práticas. Sobre a teoria da acção. Oeiras: Celta.

Cabral, João de Pina (1993), "A lei e a paternidade: as leis de filiação portuguesas vistas à luz da antropologia social”, Análise Social, 123-124, 975-997.

Caillé, Alain (2000), Anthropologie du don. Le tiers paradigme. Paris: Desclée de Brouwer.

Caillé, Alain (2003), "Dádiva, cidadania e democracia”, in Alzira Medeiros; Paulo Henrique Martins (orgs.), Economia popular e solidária. Desafios teóricos e práticos. Recife: Edições Bagaço,16-25.

Chaland, Karine (2001), "Pour une usage sociologique de la double généalogie philosophique de l'individualisme”, in François de Singly (org.), Etre soi d'un âge à l'autre. Paris: L'Harmattan, 31-43.

Cicchelli, Vincenzo; Martin, Claude (2004), "Young Adults in France: Becoming Adult in the Context of Increased Autonomy and Dependency", Journal of Comparative Family Studies, 35(4), 615-626.

Coenen-Hunter, Josette; Kellerhals, Jean; von Allmen, Malik (1994), Les réseaux de solidarité dans la famille. Lausanne: Éditions Réalités Sociales.

Déchaux, Jean-Hugues (1990a), "Les échanges économiques au sein de la parentèle”, Sociologie du Travail, 1, 73-94.

Déchaux, Jean-Hugues (1990b), “Des relations de parenté inédites?”, Esprit, 91-101.

Degenne, Alain; Forsé, Michel (1994), Les réseaux sociaux. Paris: Armand Colin.

Degenne, Alain; Lebeaux, Marie-Odile (1997), “Qui aide qui, pour quoi?”, L'Année Sociologique, 47(1), 117-141.

Ferrand, Alexis (1992), "Les réseaux de relations personnelles", Actes du Séminaire "Du politique et du social dans l'avenir de la famille”. Paris: La Documentation Française, 79-90.

Finch, Janet (1989), Family Obligations and Social Change. Cambridge: Polity Press.

Finch, Janet; Mason, Jennifer (1993), Negotiating Family Responsibilities. London: Routledge.

Giddens, Anthony (1994), Modernidade e identidade pessoal. Oeiras: Celta.

Giddens, Anthony (1995), Transformações da intimidade. Sexualidade, amor e erotismo nas sociedades modernas. Oeiras: Celta.

Godbout, Jacques T. (1995), "La norme de justice dans les relations de parenté”, L'Année Sociologique, 45(2), 351-370.

Godbout, Jacques T. (2000), Le don, la dette et l'identité. Paris: La Découverte. 
Granovetter, Mark S. (1973), “The Strength of Weak Ties”, American Journal of Sociology, 78, 1360-1380.

Granovetter, Mark S. (1982), "The Strength of Weak Ties: A Network Theory Revisited”, in Peter V. Marsden; Nan Lin (orgs.), Social Structure and Network Analysis. Beverly Hills: Sage, 105-130.

Grundy, Emily (2005), "Reciprocity in Relationships: Socio-economic and Health Influences on Intergenerational Exchanges Between Third Age Parents and their Adult Children in Great Britain”, British Journal of Sociology, 56(2), 233-255.

Guerreiro, Maria das Dores; Abrantes, Pedro (2004), Transições incertas: os jovens perante o trabalho e a família. Lisboa, DGEEP/ CITE.

Hockey, Jenny; James, Allison (1993), Growing Up and Growing Old. Ageing and Dependency in the Life Course. London: Sage.

Jones, Gill (1992), "Short-term Reciprocity in Parent-Child Economic Exchanges", in Catherine Marsh; Sara Arber (orgs.), Families and Households. Divisions and Change. London: MacMillan Press, 26-44.

Kellerhals, Jean; Coenen-Huther, Josette; Modak, Marianne (1987), "Stratification sociale, types d'interaction dans la famille et justice distributive”, Revue Française de Sociologie, XXVIII, 217-240.

Kellerhals, Jean; Coenen-Huther, Josette; Modak, Marianne (1988), Figures de l'équité. La construction des normes de justice dans les groupes. Paris: PUF.

Kellerhals, Jean; Modak, Marianne; Sardi, Massimo (1995), "Justice, sens de la responsabilité et relations sociales”, L'Année Sociologique, 45(2), 317-349.

Lemieux, Vincent (1999), Les réseaux d'acteurs sociaux. Paris: PUF.

Martin, Claude (1995), "Os limites da protecção da família. Introdução a uma discussão sobre as novas solidariedades na relação família-Estado”, Revista Crítica de Ciências Sociais, 42, 53-76.

Martin, Claude (1996), "Solidarités familiales: débat scientifique, enjeu politique", in Jean-Claude Kaufmann, Faire ou faire-faire? Familles et services. Rennes: Presses Universitaires de Rennes, 55-73.

Martins, Paulo Henrique (2005), “A sociologia de Marcel Mauss: Dádiva, simbolismo e associação", Revista Crítica de Ciências Sociais, 73, 45-66.

Martuccelli, Danilo (2002), Grammaires de l'individu. Paris: Gallimard.

Mauss, Marcel (1988), Ensaio sobre a dádiva. Lisboa: Edições 70.

Mermet, Jean-Claude (1991), "Le Lien de famille: la reciprocité en défaut", Revue du MAUSS, 12, 137-146.

Portugal, Sílvia (2006), Novas famílias, modos antigos. As redes sociais na produção de bem-estar. Coimbra: FEUC (diss. de doutoramento).

Rospabé, Philippe (1996), "L’obligation de rendre”, Revue du MAUSS, 8, 142-152.

Schaber, Gaston (1995), "Don de temps, don d'argent, don d'espace”, in Claudine Attias-Donfut (org.), Solidarités entre générations. Vieillesse, familles, État. Paris, Nathan, 97-115. 
Schmidt, Luísa (1990), “Jovens: família, dinheiro, autonomia”, Análise Social, 108-109, 645-673.

Sennett, Richard (2001), A corrosão do carácter. Lisboa: Terramar.

Sennett, Richard (2004), Respect in a World of Inequality. New York: W. W. Norton \& Company.

Singly, François de (2001a), Libres ensembles. L'individualisme dans la vie commune. Paris: Nathan.

Singly, François de (2001b), "La naissance de l'individu individualisé et ses effets sur la vie conjugale et familiale”, in François de Singly (org.), Etre soi parmi les autres. Paris: L'Harmattan, 5-14.

Singly, François de (org.) (2001c), Etre soi parmi les autres. Paris: L'Harmattan.

Singly, François de (org.) (2001d), Être soi d'un âge à l'autre. Paris: L'Harmattan.

Singly, François de (2003), Les uns avec les autres. Quand l'individualisme crée du lien. Paris: Armand Colin.

Singly, François de (2004), Sociologie de la famille contemporaine. Paris: Armand Colin.

Therborn, Göran (2002), "Back to Norms! On the Scope and Dynamics of Norms and Normative Action”, Current Sociology, 50(6), 863-880.

Torres, Anália et al. (2004), Homens e mulheres entre trabalbo e família. Lisboa: DEEP/ CID.

Wall, Karin (1998), Famílias no campo. Passado e presente em duas freguesias do Baixo Minho. Lisboa: D. Quixote. 